\section{WOOD DUCKS BREEDING ALONG THE NORTH SASKATCHEWAN RIVER NEAR FORT CARLTON}

Dale Hjertaas

15 Olson Place

Regina, SK S4S $2 J 6$

During June 2018 my daughter, Estelle Hjertaas, and I spent three days canoeing the North Saskatchewan River from the Borden Bridge to Prince Albert. While canoeing we observed three female Wood Ducks (Aix sponsa) with broods, outside the reported breeding range for the Wood Duck in Saskatchewan.

We observed a female with four ducklings on 28 June about $4.5 \mathrm{~km}$ upstream of Fort Carlton. The female was identified by the white patch around and extending behind the eye. I referred to my field guide at the time to confirm the identification. ${ }^{1}$ I was also familiar with Wood Duck field marks from previous observations. After visiting Fort Carlton, we paddled about 17 $\mathrm{km}$ to an island $5.5 \mathrm{~km}$ downstream of the Wingard Ferry. On this stretch we observed a female Wood Duck with eight ducklings. On 29 June, as we paddled $65 \mathrm{~km}$ to reach Prince Albert, we observed a third brood, a female with nine recently hatched ducklings, somewhere upstream from the major bend in the river near Lily Plain.

Also in 2018, on 21 July, Stan Shadick and John Patterson observed a female with a brood of at least three ducklings about $9 \mathrm{~km}$ west of the North Saskatchewan River and $15 \mathrm{~km}$ northeast of Borden. The location was "a ditch near a slough near northing 5817000 and easting
360100" (pers comm Stan Shadick 7 April 2020).

In 2013, Harold Fisher located a Wood Duck nest with 11 eggs in a nest box $13 \mathrm{~km}$ SE of Prince Albert. ${ }^{2}$ The area around the aspen supporting the nest box had been flooded during the wet years, creating suitable habitat for the Wood Duck.

Birds of Saskatchewan gives the breeding range of the Wood Duck as "mainly in the Saskatchewan River lowlands and along the Qu'Appelle and Souris rivers". ${ }^{3}$ The range map also shows three isolated breeding localities, one near Prince Albert and two along the South Saskatchewan River.

Our observations of three broods on the North Saskatchewan River between Highway 12 and Lily Plain, the observation by Shadick and Patterson and the observation by Fisher indicate an established breeding population, and an extension of the known breeding range, along and adjacent to the North Saskatchewan River from Prince Albert westward as far as Borden.

1. Peterson, RT (2010) Peterson Field Guide to the Birds of Western North America. Fourth Edition. Houghton Mifflin Harcourt, New York.

2. Fisher, H (2014) A Breeding Record for Wood Duck (Aix sponsa) in Central Saskatchewan. Blue Jay 72(4):200-202.

3. Dickson RD (2019) Wood Duck. Pages 59-60 in Birds of Saskatchewan (Smith AR, Houston CS, Roy JF, editors). Nature Saskatchewan, Regina.

\section{POETRY}

\section{Third Day of Autumn}

A cold morning

Blue-grey and shrouded,

From the chill rain

Of the night before

Just above frost.

But as the new sun

Chases off the mist

Rolling up from the

lake valley,

And rising from the

drenched grasses,

One lone meadowlark

From his bare

buffalo berry perch

Brazenly pipes his

Summer song.

\section{George Grassick}

Box 205

Lumsden, SK

SOG 3CO

ggrassick@sasktel.net 